\title{
Sarcoid-Like Reaction Mimicking Nodal Spread of Lung Cancer in a Silica-Exposed Patient on Positron Emission Tomography/Computed Tomography: A Case Report
}

\author{
Silika Maruziyetli Hastada PET/BT 'de Akciğer Kanserinin Nodal Yayılımını \\ Taklit Eden Sarkoid Benzeri Reaksiyon: Olgu Sunumu
}

Feyza Şen', Ahmet Sami Bayram², Mehmet Karadağํํㄹ Elif Ülker Akyıldız

\section{Abstract}

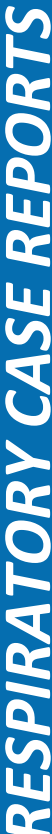

As a noninvasive modality, Fluorine-18 Fluorodeoxyglucose (FDG) positron emission tomography/computed tomography (PET/CT) is an important first step to assess mediastinal lymph node (LN) status in malignant pulmonary lesions. However, incorrect upstaging may occur due to false-positive results. Determining $N$ stage is of utmost importance, and will affect the treatment planning strategy. Presently described is a staging challenge with PET/CT in a silica-exposed patient who was evaluated for characterization of a lung mass. The mass had an intense FDG uptake and proved to be squamous cell lung cancer (squamous cell carcinoma [SCC]) after a lobectomy. Histopathology revealed non-caseating granulomas representing sarcoid-like reaction (SLR) in non-calcified hypermetabolic mediastinal-hilar LNs. The significance of such reactions lies in how they can give a false impression of upstaging on the initial PET/CT or mimic disease progression after treatment. As an underlying clinical manifestation, occupational history is also discussed as a confounding factor for a benign cause of mediastinal lymphadenopathy. Awareness of tumor-related SLR is needed to avoid false positive PET/CT interpretation. To obtain histological confirmation of $\mathrm{LNs}$ for accurate staging in such a circumstance is also emphasized.

Key words: PET/CT, silica exposure, occupational disease, granulamatous disease.

\section{Özet}

Malign pulmoner lezyonlarda mediastinal lenf nodu durumunun değerlendirilmesinde non-invaziv bir görüntüleme yöntemi olan PET/BT önemli bir ilk adım sayılmaktadır. Bununla birlikte yanlış pozitifliklere bağlı hatalı evre yükseltilmesi söz konusu olabilir. N evresinin belirlenmesi, tedavi planlama stratejisini etkileyebilecek son derece önemli bir durumdur. Silika maruziyeti olan bu olguyu akciğerindeki kitle karakterizasyonu için yapılan PET/BT'sinde karşılaşılan evreleme güçlüğü nedeniyle sunuyoruz. Yoğun FDG uptake'i gösteren kitlenin lobektomi sonrası histopatolojik olarak skuamöz hücreli kanser olduğu kanıtlanmasına rağmen beraberindeki kalsifiye olmayan hipermetabolik lenf nodlarının sarkoid benzeri reaksiyonu temsil eder şekilde non-kazeöz granülom ile uyumlu olduğu değerlendirildi. Bu tarz reaksiyonların önemi, ilk evreleme PET/BT'de ileri evreye yükseltilme ya da tedavi sonrası hastalık progresyonu olduğuna dair yanlış bir izlenim oluşturmasında yatmaktadır. Mediastinal lenf nodlarının benign nedenlerinden birisi olarak çelişkiye yol açan altta yatan meslek öyküsü ayrıca tartışılmıştır. PET/BT'nin yanlış pozitif olarak değerlendirilmemesi için tümör ile ilişkili sarkoid benzeri reaksiyonun farkındalığı gerekmektedir. Böyle bir durumda doğru evrelendirme için lenf nodlarının histolojik olarak konfirme edilmesi gerekliliği vurgulanmıştır.

Anahtar Sözcükler: PET/BT, silica maruziyeti, meslek hastalığı, granülamatöz hastalık.

'Uludağ Üniversitesi Tıp Fakültesi, Nükleer Tıp AD, Bursa 2Uludağ Üniversitesi Tıp Fakültesi, Göğüs Cerrahi AD, Bursa ${ }^{3}$ Uludağ Üniversitesi Tıp Fakültesi, Göğüs Hastalıkları AD, Bursa

${ }^{4}$ Uludağ Üniversitesi Tıp Fakültesi, Patoloji AD, Bursa

'Department of Nuclear Medicine, Uludağ University Faculty of
Medicine, Bursa, Turkey
${ }^{2}$ Department of Thoracic Surgery, Uludağ University Faculty of
Medicine, Bursa, Turkey
${ }^{3}$ Department of Pulmonary Medicine, Uludağ University Faculty of
Medicine, Bursa, Turkey
${ }^{4}$ Department of Pathology, Uludağ University Faculty of Medicine,

Bursa, Turkey

Submitted (Başvuru tarihi): 02.05.2017 Accepted (Kabul tarihi): 18.06.2017

Correspondence (iletişim): Feyza Şen, Department of Nuclear Medicine, Uludağ University Faculty of Medicine,

Bursa, Turkey

e-mail: drfeyzasen@yahoo.com 
With perfectly coregistered metabolic and morphological information, PET/CT has improved mediastinal staging of lung cancer patients. Because FDG is not a cancerspecific agent, false positive results may occur, mostly due to concurrent inflammatory processes. Among them, SLR poses a diagnostic challenge, mimicking metastatic nodal spread in patients with a history of malignancy (13). Although SLR is a well-known entity, few papers have reported its impact on patient management of lung cancer with PET/CT $(4,5)$. Presented here is a case of a silica-exposed patient who had undergone a PET/CT study to characterize a lung mass. Debate remained over metastatic nodal spread of inoperable lung carcinoma until benign non-caseating granulomas (NCG) were shown to histopathologically demonstrate SLR.

\section{CASE}

A 54-year-old-man with a long history of a cough was found to have opacity on a chest X-ray (Figure 1a). He was a dental technician who had been exposed to silica dust for nearly 30 years as a result of his occupation. Previous screening chest $X$-ray reports had been normal. He was an ex-smoker with a 30-pack-year smoking history who had quit 10 years earlier. A recent chest CT revealed a $3-\mathrm{cm}$ spiculated mass in the left upper lobe with enlarged mediastinal-hilar LNs (Figure 1b). Multiple milimetric- and subcentimetric-sized pulmonary nodules in the lung parenchyma were also detected in the subpleural areas (Figure 1c). A subsequent PET/CT scan showed high FDG uptake in the mass (Figure 2) (SUVmax: 14.0) that was highly likely to be malignant with mediastinalhilar and abdominal nodal involvement suggesting metastatic spread (Figure 3a). The thoracic hypermetabolic LNs were located at aortopulmonary (SUVmax: 6.6), lower paratracheal (SUVmax: 6.6), and left hilarinterlobar (SUVmax: 6.2) and right hilar lymphatic stations. Additionally, there were 3 other nodes (SUVmax: 7.3) at the levels of the coeliac trunk and superior mesenteric artery in the abdomen (Figure 3b). No distant metastases were detected. The case was reviewed by the Multidisciplinary Lung Cancer Tumor Board and further investigations were arranged. Mediastinoscopy was performed and biopsies were taken from the lower paratracheal and right hilar LNs. All showed reactive benign changes on the frozen section. A left upper lobectomy was performed. The histopathological examination revealed SCC with clear margins in the upper lobe mass. The adjacent pleura and peritumoral lung parenchyma were intact. All of the $L N$ s examined were reported to be benign NCG (Figure 4). No evidence of tuberculosis was detected in samples with further examination of azafluoren one staining, culture, and polymerase chain reaction analysis, as all were negative. The serum angiotensin-converting enzyme level was normal. The final clinical decision was to proceed with chemotherapy because of the size of the tumor. Three months after surgery the patient was clinically well.
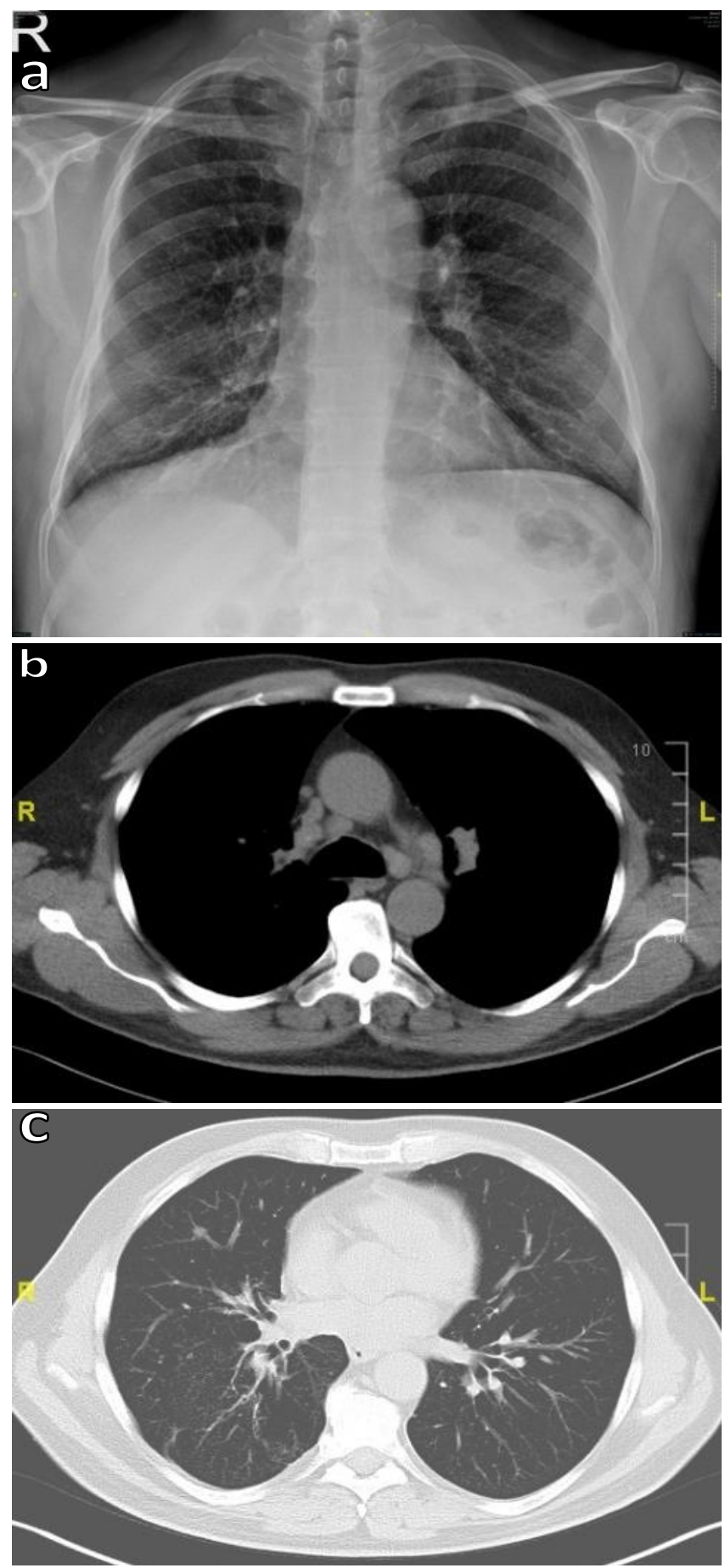

Figure $1 a, b$ and $c$ : Chest $X$-ray ( $a$ ), transaxial computed tomography slices from the mediastinal (b), and lung (c) windows 


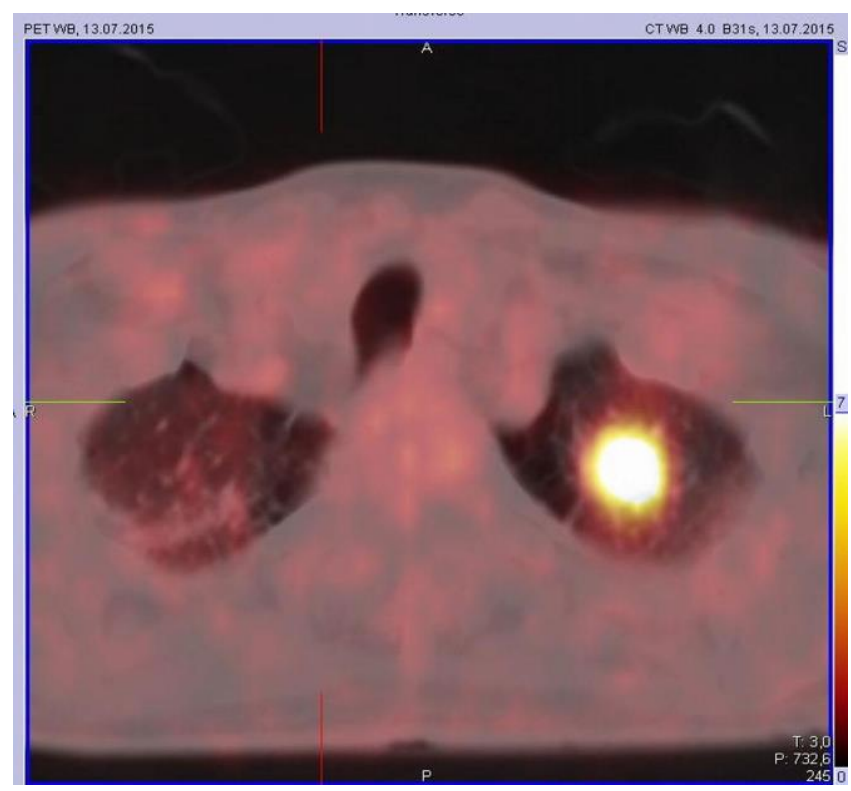

Figure 2: Transaxial slice of positron emission tomography/computed tomography fusion images showing the left upper lobe lung mass with spiculated borders and increased fluorine- 18 fluorodeoxyglucose uptake

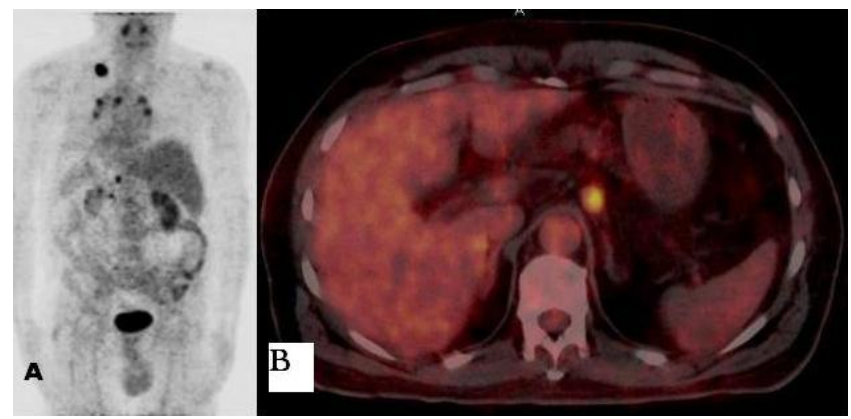

Figure $3 a$ and $b$ : Maximum intensity projection image clearly demonstrates the primary tumor with high fluorine-18 fluorodeoxyglucose uptake and the symmetrical pattern of the mediastinal hypermetabolic lymph nodes (a). Abdominal lymph node involvement is also seen in the left para-aortic region both on maximum intensity projection (a), and the transaxial view (b)

\section{DISCUSSION}

Mediastinal lymphadenopathy with lung cancer is suggestive of nodal spread, but can also have other origins (4). Concurrent inflammatory processes are great mimickers for false positivity, leading to incorrect upstaging, which affects patient management. We report a challenging instance of nodal staging in a silica-exposed patient who was evaluated for the characterization of a lung mass. The high FDG uptake and malignant features on corresponding $C T$ slices suggested a malignant primary tumor on PET/CT, which was subsequently proven to be SCC. For nodal status assessment on $\mathrm{PET} / \mathrm{CT}$, visual criteria have been a typical method, and semiquantitative interpretation with SUVmax has also been used to support visual data by indicating the degree of metabolic activity. However, SUVmax overlap may occur between benign and malignant mediastinal LNs, and there has been no clear consensus on which SUVmax threshold distinguishes malignant from inflammatory processes (6). SUVmax cutoff may also vary depending on a high prevalence of inflammation/infection in a specific region of the body, such as the chest (7).

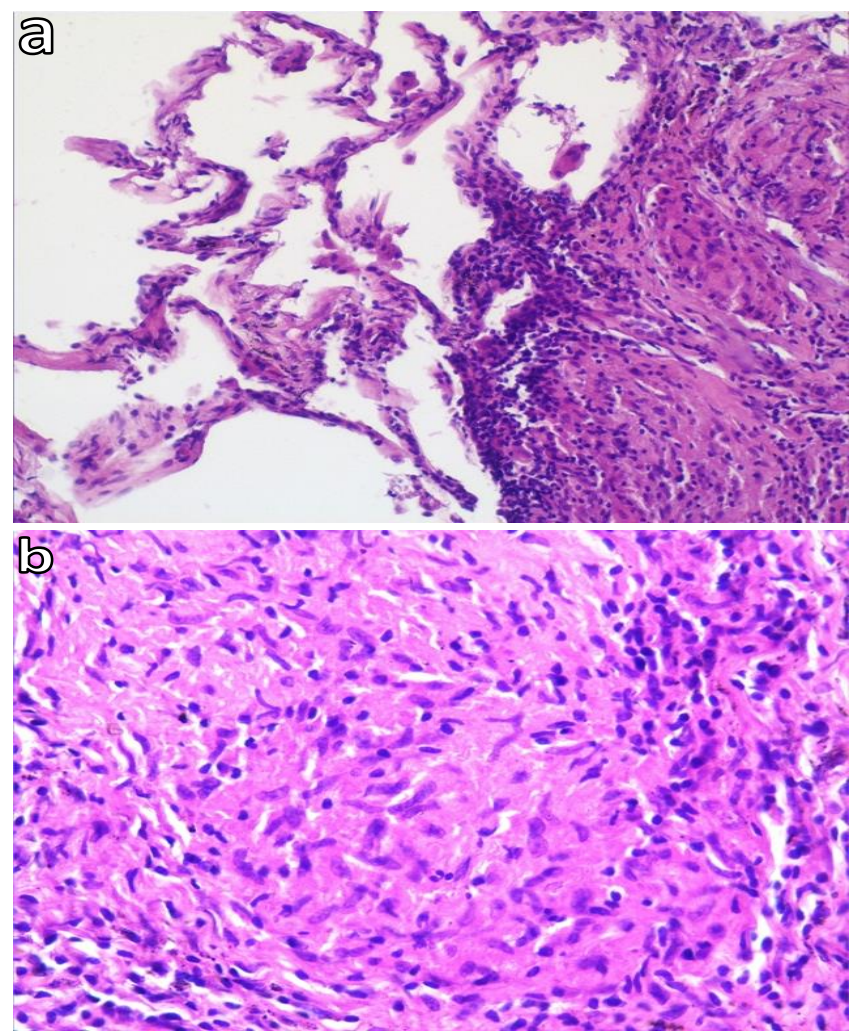

Figure 4a and b: Non-caseating granuloma representing sarcoid-like reaction histopathologically with hematoxylin and eosin (H\&E) x200 (a), and $H \& E \times 400$ (b)

In this case, despite the somewhat symmetric nodal uptake, the lymphatic pattern was highly suspicious for metastatic spread. There was also the possibility of a benign reactive etiology, mainly due to occupational history. The patient had long been exposed to silica particles, but no evidence of the classic imaging features of silicosis, such as eggshell calcification of hilar LNs, was found. That reduced the likelihood of benign etiology. The SUVmax of individual mediastinal $\mathrm{LNs}$ is known to predict malignancy (8). Despite a high SUVmax on PET/CT, the mediastinal LNs showed benign NCG compatible with SLR histopathologically, and confirmed our suspicion of false positivity. Thus, the abdominal LNs were also considered to be benign and a biopsy was not performed. Nevertheless, the probability of gastric malignancy was ruled out by endoscopy. The development of NCG in patients with cancer and no other signs or symptoms of sarcoidosis is referred to as SLR (1-3). Although the pathophysiology is 
not clear, the granulomas are thought to form as an immune response to neoplastic antigens (3). SLR has been documented in association with several types of malignancy, including lung cancers, and their draining LNs. Antineoplastic treatment may potentially evoke SLR, but it can rarely be seen at the time of diagnosis on staging PET/CT scans, as in our case. The most common pattern of SLR is reported to be mediastinal and/or symmetric hilar LN uptake. Distribution to distant $L N s$ and some organs has also been reported. The pathological diagnosis of NCG is nonspecific, and histologically, the granulomas of SLR are indistinguishable from granulomas of sarcoidosis. No signs of sarcoidosis and no other organ involvement were detected clinically in this male patient. However, a diagnosis of sarcoidosis could not be excluded.

Silicosis is an occupational disease caused by the inhalation of dust containing free crystalline silica. A high level of dust exposure is required for pulmonary silicosis; otherwise clinically significant lung disease may not occur, as in our case. Regional LN involvement, including the anterior cervical nodes, aortic chains, celiac axis, and porta hepatis may also occur as an extrapulmonary effect in exposed individuals that have no evidence of lung disease (9). We speculated that the scenario other than SLR might have been a granulamatous inflammatory response provoked in the LNs due to repeated inhalation of silica.

This case illustrates that the interpretation of the nodal status of enlarged and hypermetabolic LNs with PET/CT is a challenge in mixed clinical manifestations. Either lung cancer alone or concurrent with occupational exposure to chemicals may trigger SLR in regional or draining $L N s$ that produces a false positive interpretation of nodal spread. The importance of obtaining histological confirmation of LNs for accurate staging in such a circumstance is also emphasized.

\section{CONFLICTS OF INTEREST}

None declared.

\section{AUTHOR CONTRIBUTIONS}

Concept - F.S., A.S.B., M.K., E.Ü.A.; Planning and Design - F.Ş., A.S.B., M.K., E.Ü.A.; Supervision - F.Ş., A.S.B., M.K., E.Ü.A.; Funding - F.Ş., A.S.B.; Materials - F.S.,, A.S.B.; Data Collection and/or Processing - F.Ş., A.S.B., M.K., E.Ü.A.; Analysis and/or Interpretation - F.S..; Literature Review - F.Ş.; Writing - F.Ş.; Critical Review - F.Ş.

\section{YAZAR KATKILARI}

Fikir - F.Ş., A.S.B., M.K., E.Ü.A.; Tasarım ve Dizayn - F.S.., A.S.B., M.K., E.Ü.A.; Denetleme - F.Ş., A.S.B., M.K., E.Ü.A.; Kaynaklar - F.Ş., A.S.B.; Malzemeler - F.S.., A.S.B.; Veri Toplama ve/veya İşleme - F.Ş., A.S.B., M.K., E.Ü.A.; Analiz ve/veya Yorum - F.Ş.; Literatür Taraması - F.Ş.; Yazıyı Yazan - F.Ş.; Eleştirel İnceleme - F.Ş.

\section{REFERENCES}

1. Koo HJ, Kim MY, Shin SY, Shin S, Kim SS, Lee SW, et al. Evaluation of mediastinal lymph nodes in sarcoidosis, sarcoid reaction, and malignant lymph nodes using CT and FDG-PET/CT. Medicine (Baltimore) 2015; 94:e1095. [CrossRef]

2. Craun JB, Banks KP, Clemenshaw MN, Moren RW. Sarcoidlike reaction of neoplasia causing hypermetabolic thoracic adenopathy in setting of extrathoracic malignancy: report of two cases and a review of the differential diagnostic considerations. J Nucl Med Technol 2012; 40:231-5. [CrossRef]

3. Chowdhury FU, Sheerin F, Bradley KM, Gleeson FV. Sarcoid-like reaction to malignancy on whole-body integrated (18) F-FDG PET/CT: prevalence and disease pattern. Clin Radiol 2009; 64:675-81. [CrossRef]

4. Schook RM, Koudstaal L, Comans EF, Postmus PE, Grünberg K, Paul MA, et al. Benefit of a second opinion: From metastatic disease to resectable lung cancer with sarcoid-like reaction. Respir Med Case Rep 2014; 13:26-7. [CrossRef]

5. Kuś E, Gabryś J, Czyżewski D. False positive result of 18F-FDG PET in patient with lung cancer due to sarcoidlike reaction in regional lymph nodes. Pneumonol Alergol Pol 2014; 82:548-54.

6. Hellwig D, Graeter TP, Ukena D, Groeschel A, Sybrecht GW, Schaefers HJ, et al. 18F-FDG PET for mediastinal staging of lung cancer: which SUV threshold makes sense? J Nucl Med 2007; 48:1761-6. [CrossRef]

7. Nguyen NC, Kaushik A, Wolverson MK, Osman MM. Is there a common SUV threshold in oncological FDG $\mathrm{PET} / \mathrm{CT}$, at least for some common indications? A retrospective study Acta Oncol 201 1; 50:670-7. [CrossRef]

8. Bryant AS, Cerfolio RJ, Klemm KM, Ojha B. Maximum standard uptake value of mediastinal lymph nodes on integrated FDG-PET-CT predicts pathology in patients with non-small cell lung cancer. Ann Thorac Surg 2006; 82:417-22. [CrossRef]

9. Adverse effects of crystalline silica exposure. American Thoracic Society Committee of the Scientific Assembly on Environmental and Occupational Health. Am J Respir Crit Care Med 1997; 155:761-8. 